\title{
GAMBARAN PERILAKU KELUARGA DALAM PENGATURAN DIET HIPERTENSI PADA LANSIA DI RT 03 DAN RT 04 RW 06 KELURAHAN DARMO SURABAYA
}

\author{
*Suci Dia Anit, **Wijar Prasetyo \\ AKPER William Booth Surabaya, Jl. Cimanuk No.20 Surabaya,wijar85@gmail.com
}

\begin{abstract}
ABSTRAK
Keluarga sangat berperan dalam merawat lansia terutama pada lansia yang menderita hipertensi terutama dalam cara pengaturan diet. Selama ini peneliti melihat di Kelurahan Darmo masih banyak keluarga yang menyediakan makanan untuk lansia yang menderita hipertensi dengan cara pengaturan dan makanan yang dimasak masih mengikuti menu keluarga yang lain. Tujuan penelitian ini adalah untuk mengetahui gambaran perilaku keluarga dalam pengaturan diet hipertensi pada lansia di RT 03 dan RT 04 RW 06 Kelurahan Darmo Surabaya. Penelitian ini menggunakan desain penelitian deskriptif dengan populasi sebanyak 22 orang tetapi setelah melakukan data skrining dari rumah ke rumah didapatkan populasi sebanyak 15 orang dan semua dijadikan sampel. Dengan menggunakan teknik total sampling pengumpulan data dilakukan dengan menggunakan lembar cheklist. Dari data penelitian didapatkan responden dengan perilaku buruk sebanyak 8 responden $(53,3 \%)$ dan perilaku baik sebanyak 7 responden (46,7\%). Dari data diatas dapat disimpulkan perilaku keluarga dalam pengaturan diet hipertensi pada lansia di RT 03 dan RT 04 RW 06 Kelurahan Darmo Surabaya berperilaku buruk. Perilaku dapat dipengaruhi oleh berbagai faktor dimana setiap individu memiliki perbedaan karakteristik perilakunya tergantung dari individu itu sendiri khususnya dalam perencaan kesehatan baik pada dirinya maupun keluarganya.
\end{abstract}

Kata kunci : Perilaku, Keluarga, Diet Hipertensi

\begin{abstract}
Family really gets role for taking care of elderly especially on elderly who suffer hypertension specifically in diet arrangement trick. All this time the researcher saw in Darmo's sub-districts stills many of family which victuals for elderly what does suffer hypertension, arrangement and food trick that cooked still follow other family member. The objective of this study is to know family behavior in hypertension diet arrangement on elderly at RT 03 and RT 04 RW 06 Darmo Surabaya's sub-districts. This research utilized descriptive research design with population 22 person but after do screening's data of door to door being gotten populations as 15 persons and all made by samples. Total sampling was used in this study with data collecting done used checklist. Based on this research got the respondent with bad behavior as 8 respondents $(53,3 \%)$ and good behavior as 7 respondents $(46,7 \%)$. Based on them could be concluded that families behavior in hypertension diet arrangement on elderly at RT 03 and RT 04 RW 06 Darmo's sub-districts surabaya majority showed bad behavior. The behavior could be influenced by various factor which each person have different behavior characteristic depended on the individual itself specifically in term of how to manage his own health or his family.
\end{abstract}

Key word: Behavior, Family, Hypertension diet 


\section{Pendahuluan}

Seseorang dapat dinyatakan sebagai seorang lansia setelah yang bersangkutan mencapai umur 55 tahun, tidak berdaya mencari nafkah sendiri untuk keperluan hidupnya sehari-hari dan menerima nafkah dari orang lain. (UU no 4 tahun 1998, dikutip dari Wahyudi, 2000). Menurut BKKBN, 1995, Lansia adalah individu yang berusia di atas 60 tahun, pada umumnya memiliki tanda-tanda terjadinya penurunan fungsi biologis, psikologis, sosial dan ekonomi (Mubarak, 2009). Menurut Duvall, keluarga adalah sekumpulan orang yang dihubungkan oleh ikatan perkawinan, adopsi, kelahiran yang bertujuan menciptakan dan mempertahankan budaya yang umum, meningkatkan perkembangan fisik, mental, emosional dan sosial setiap anggota keluarga (Mubarak, 2009). Peran keluarga dalam merawat lansia yaitu menjaga dan merawat kondisi fisik lansia agar tetap dalam keadaan optimal atau produktif, mempertahankan dan meningkatkan status mental lansia, mengantisipasi adanya perubahan sosial dan ekonomi pada lansia serta memotivasi dan memfasilitasi lansia untuk memenuhi kebutuhan spiritual, sehingga ketakwaan lansia kepada Tuhan Yang Maha

Malang tahun 2008 menunjukkan bahwa pada pola pengaturan diet $71,9 \%$ responden biasa menambahkan bumbu-bumbu masakan seperti kecap, terasi, saus sambal dan lain-lain. Sedangkan jenis diet yang biasa dikonsumsi, $93,8 \%$ responden biasa mengkonsumsi tempe dan $96,9 \%$ responden biasa menggunakan bawang merah sebagai bumbu masaknya. Pola diet yang kurang sesuai adalah kebiasaan menambahkan bumbu-bumbu masakan seperti kecap, vetsin, terasi, saus sambal $(71,9 \%$ responden). Dari studi awal, dari 5 keluarga yang diwawancara oleh peneliti, 4 keluarga di tempat tinggal saya suka mengkonsumsi makanan yang asin karena kalau tidak asin tidak enak. Menurut data skrining, dari 22 lansia yang ada lansia yang menderita hipertensi di tempat tinggal saya sebanyak 15 orang.

Peran keluarga dalam merawat lansia salah satunya dengan cara keluarga menjaga kondisi fisik lansia agar tetap dalam keadaan optimal. Dalam hal ini, keluarga yang memiliki lansia dengan hipertensi perlu memperhatikan diet hipertensi yang benar. Apabila keluarga memberikan diet yang salah pada lansia yang mengalami hipertensi maka akan
Esa meningkat (Mubarak, 2009). Keluarga sangat berperan dalam merawat lansia terutama pada lansia yang menderita hipertensi. Dalam hal ini, keluarga berfungsi sebagai the health care function yaitu merawat dan memelihara kesehatan anggota keluarga agar tetap memiliki produktivitas yang tinggi dengan cara mengolah makanan pada lansia yang menderita hipertensi. Selama ini yang saya lihat di tempat tinggal saya, banyak keluarga yang menyediakan makanan untuk lansia yang menderita hipertensi, cara pengaturan dan makanan yang dimasak masih mengikuti menu dengan keluarga yang lain. Disamping itu di tempat tinggal saya ditemukan 3 orang terkena stroke dan 1 diantaranya meninggal.

Di Indonesia, berdasarkan penelitian Sja'bani (2008), penderita hipertensi yang periksa di Puskesmas dilaporkan teratur sebanyak 22,8\%, sedangkan tidak teratur sebanyak 77,2\%. Hipertensi pada akhirnya juga berdampak pada ekonomi masyarakat dan pemerintah. Penderita hipertensi di negara berkembang mencapai $37 \%$ pada tahun 2000 dan diperkirakan menjadi $42 \%$ pada tahun 2025 nanti. Hasil penelitian oleh Harjanti di

menyebabkan komplikasi hipertensi. Hipertensi yang tidak terkontrol mengakibatkan terjadinya trombo emboli dan serangan iskemia otak. Akibatnya lansia jatuh dan terkena stroke, kemungkinan yang bisa terjadi pada lansia yang sudah terkena stroke, tidak bisa melakukan aktifitas untuk memenuhi kebutuhan sehari-hari. Kematian bisa juga terjadi pada lansia yang menderita hipertensi akibat pecahnya pembuluh darah otak arteri. Peningkatan tekanan darah yang terus menerus pada klien hipertensi esensial akan mengakibatkan kerusakan pembuluh darah organ-organ vital. Hipertensi esensial mengakibatkan hyperplasia medial (penebalan) arteriole-arteriole. Karena pembuluh darah menebal, maka perfusi jaringan menurun dan mengakibatkan kerusakan organ tubuh. Hal ini menyebabkan infark miokard, stroke, gagal jantung, dan gagal ginjal. (Udjianti, 2010)

Dalam mengatasi masalah ini, keluarga perlu diberikan penyuluhan mengenai penyajian diet pada lansia yang menderita hipertensi dan menganjurkan klien mematuhi diet untuk mencegah terjadinya komplikasi hipertensi yang dapat membahayakan 
hidupnya serta menganjurkan klien untuk kontrol rutin dan berkoordinasi dengan puskesmas terdekat dalam memberikan penyuluhan tentang pencegahan hipertensi khususnya tentang diet hipertensi. Dalam hal ini fungsi keluarga sangat berpengaruh penting dalam pengaturan diet hipertensi pada lansia. Untuk itu peneliti tertarik untuk melakukan penelitian dengan judul "Gambaran perilaku keluarga dalam pengaturan diet hipertensi pada lansia di RT 03 dan RT 04 RW 06 Kelurahan Darmo Surabaya“"

\section{Bahan dan Metode}

Desain penelitian adalah rencana penelitian yang disusun sedemikian rupa sehingga peneliti dapat memperoleh jawaban terhadap pertanyaan penelitian. (Setiadi, 2007). Berdasarkan tujuan penelitian desain penelitian yang digunakan adalah desain deskriptif untuk mengetahui gambaran perilaku terhadap pengaturan diet hipertensi pada lansia.

Variabel adalah karakteristik yang diamati yang mempunyai variasi nilai dan merupakan operasionalisasi dari suatu konsep agar dapat diteliti secara empiris atau ditentukan tingkatannya (Setiadi, 2007). Variabel dalam penelitian ini yaitu perilaku keluarga dalam cara pengaturan diet hipertensi.

Populasi adalah keseluruhan subjek penelitian yang akan diteliti (Notoatmodjo, 1993 yang dikutip dari Setiadi, 2007). Pada penelitian ini populasi adalah Seluruh keluarga yang memiliki lansia di RT 03 dan RT 04 RW 06 Kelurahan Darmo Surabaya. Sampling yang dipakai adalah total sampling. Sampel pada penelitian ini adalah semua keluarga yang memiliki lansia dengan hipertensi di RT 03 dan RT 04 RW 06 Kelurahan Darmo Surabaya dengan kriteria merupakan salah satu anggota keluarga yang tinggal serumah dengan lansia hipertensi di RT 03 dan RT 04 RW 06 Kelurahan Darmo Surabaya.

Instrumen penelitian yang digunakan dalam penelitian adalah quesioner yang berjumlah 15 soal. Penelitian ini dilakukan di wilayah RT 03 dan RT 04 RW 06 Kelurahan Darmo Surabaya dengan waktu penelitian pada tanggal 26 Maret-21 April 2012.

\section{Hasil}

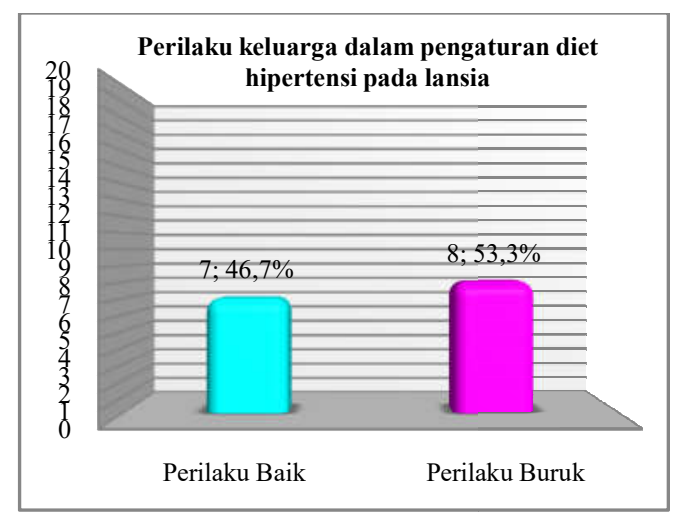

Diagram Batang 4.5 Perilaku keluarga dalam pengaturan diet hipertensi pada lansia di RT 03 dan RT 04 RW 06 Kelurahan Darmo Surabaya tanggal 28 Maret-21 April 2012.

Berdasarkan diagram batang 4.5 menunjukkan bahwa gambaran perilaku keluarga dalam pengaturan diet hipertensi pada lansia di RT 03 dan RT 04 RW 06 Kelurahan Darmo adalah berperilaku buruk sebanyak 8 responden $(53,3 \%)$.

\section{Pembahasan}

Berdasarkan diagram batang 4.5 menunjukkan bahwa perilaku keluarga dalam pengaturan diet hipertensi pada lansia di RT 03 dan RT 04 RW 06 Kelurahan Darmo adalah berperilaku buruk sebanyak 8 responden $(53,3 \%)$.

Menurut Notoatmojo (2003) determinan perilaku ini dapat dibedakan menjadi dua, yaitu faktor internal dan faktor eksternal. Faktor internal yakni karakteristik orang yang bersangkutan yang bersifat given atau bawaan, misalnya: tingkat kecerdasan, tingkat emosional, jenis kelamin, dan sebagainya sedangkan faktor eksternal yakni lingkungan, baik lingkungan fisik, sosial, budaya, ekonomi, politik dan sebagainya.

Dari hal diatas dapat disimpulkan bahwa perilaku dapat dipengaruhi oleh berbagai faktor. Perilaku setiap individu berbeda-beda tergantung dari karakteristik individu itu sendiri.

Berdasarkan jenis kelamin responden dimana sebagian besar responden adalah perempuan. Menurut Notoatmojo (2003) perempuan sering kali berperilaku atas dasar perasaan sebaliknya laki-laki cenderung bertindak dengan menggunakan rasionalnya. Dalam pengaturan diet, perempuan cenderung berperan dalam mengatur diet sedangkan laki- 
laki lebih cenderung bersikap acuh tak acuh. Hal ini dapat disebabkan karena perempuan lebih berperan dalam urusan rumah tangga terutama memasak sedangkan laki-laki lebih berperan sebagai kepala rumah tangga yang mencari nafkah bagi keluarganya.

Berdasarkan status responden didapatkan bahwa sebagian besar responden adalah berstatus sebagai anak. Menurut Setiadi (2008) keluarga terjadi jika memiliki hubungan darah dan adanya ikatan emosional. Anak memang mempunyai ikatan batin yang kuat dengan orang tuanya. Anak lebih cenderung mempunyai perasaan kasihan bahkan tidak tega kepada orang tuanya dibandingkan dengan anggota keluarga yang lain seperti menantu, cucu, bahkan saudara yang tinggal yang serumah. Sebagai anak kadang-kadang mereka kasihan melihat orang tuanya hanya makan sesuai diet yang dianjurkan padahal hal itu penting bagi kesehatan orang tuanya.

Berdasarkan penghasilan responden didapatkan bahwa lebih dari $50 \%$ responden dengan penghasilan dalam keluarga sebesar Rp. 500.000,- Rp.1.000.000,-. Menurut Suhardjo (1999) semakin baik perekonomian keluarga maka daya beli akan makanan juga mudah, sebaliknya semakin buruk perekonomian keluarga maka daya beli akan makanan lebih susah. Dengan penghasilan antara 500.000 1.000.000 hidup di Surabaya belum cukup untuk memenuhi kebutuhan sehari-hari. Kemungkinan masih banyak kebutuhan-kebutuhan lain yang harus dipenuhi selain diet. Penghasilan yang relatif pas-pasan dapat mempengaruhi perilaku positif keluarga dalam mengatur dan menyediakan diet.

Berdasarkan tingkat pendidikan responden didapatkan bahwa mayoritas responden dengan tingkat pendidikan SMA. Menurut Nursalam (2001) semakin tinggi tingkat pendidikan makin mudah menerima informasi sehingga semakin banyak pula pengetahuan yang dimiliki. SMA merupakan jenjang pendidikan yang cukup tinggi. Pengetahuan yang cukup belum menjamin seseorang berperilaku baik. Perilaku yang baik tidak hanya didukung dengan pengetahuan yang cukup tetapi sikap individu itu sendiri terutama dalam menentukan diet untuk keluarganya.

\section{Kesimpulan dan Saran}

Berdasarkan penelitian yang dilakukan maka dapat disimpulkan bahwa perilaku keluarga dalam pengaturan diet hipertensi pada lansia di RT 03 dan RT 04 RW 06
Kelurahan Darmo Surabaya adalah berperilaku buruk sebanyak 8 responden $(53,3 \%)$.

Dari hasil penelitian ini diharapkan pihak masyarakat melakukan kerjasama dengan puskesmas dalam melakukan pemeriksaan dan kegiatan seperti posyandu lansia, penyuluhan kesehatan khususnya tentang diet hipertensi. Penelitian ini juga sebagai masukan kepada peneliti selanjutnya untuk mengadakan penelitian tentang faktor-faktor yang mempengaruhi perilaku keluarga dalam mengatur diet hipertensi pada lansia.

\section{Daftar Pustaka}

Almatsier, Sunita. 2010. Penuntun Diet Edisi Baru. Jakarta : Gramedia Pustaka Utama.

Notoatmodjo, Soekidjo. 2003. Pendidikan dan Perilaku Kesehatan. Jakarta : PT. Asdi Mahasatya.

Nursalam, 2003. Pendekatan Praktis Metodologi Riset Keperawatan. Jakarta : CV. Agung Seto.

Nursalam, 2008. Konsep dan Perencanaan Metodologi Penelitian Ilmu Keperawatan. Jakarta : Salemba Medika

Maryam, R. Siti. 2008. Mengenal Usia Lanjut dan Perawatannya. Jakarta : Salemba Medika.

Mubarak, Wahit Iqbal. 2009. Ilmu Keperawatan Komunitas Konsep dan Aplikasi Buku 2. Jakarta : Salemba Medika.

Setiadi. 2007. Konsep dan Penelitian Riset Keperawatan. Jakarta : Graha Ilmu. 2008. Konsep dan Proses Keperawatan Keluarga. Yogyakarta :Graha Ilmu.

Suprajitno. 2004. Asuhan Keperawatan Keluarga : Aplikasi Dalam Praktik. Jakarta : EGC.

Udjianti, Wajan Juni. 2010. Keperawatan Kardiovaskuler. Jakarta : Salemba Medika. 